\title{
GROWTH PERFORMANCE AND HEMATOLOGICAL CHANGES OF GROWING NEW ZEALAND WHITE RABBITS FED DIETS SUPPLEMENTED WITH SOME NATURAL ANTIOXIDANTS UNDER HEAT STRESS CONDITIONS
}

\author{
I. El-Wardany ${ }^{1}$; A.Y. El-Badawi ${ }^{2}$; F.I.S. Helal ${ }^{2}$; Nematallah G.M. Ali ${ }^{1}$ and O.M. Aboelazab ${ }^{2}$ \\ ${ }^{1}$ Poultry Production Department, Faculty of Agriculture, Ain Shams University, Shobra El-Kheima, \\ Cairo, Egypt. \\ ${ }^{2}$ Animal Production Department, National Research Centre, Dokki, Giza, Egypt.
}

\section{SUMMARY}

$\mathrm{T}$

The present study was conducted to evaluate the effects of some natural antioxidants supplements (moringa dry leaves and rosemary) to growing rabbit diets on alleviating the negative impact of heat stress on growth performance and hematological changes. In a feeding experiment lasted 63 days, forty five growing New Zealand White (NZW) rabbits aged six weeks and weighed in average $750 \pm 5.8 \mathrm{~g}$ were randomly blocked by weight into five groups ( 9 animals each) and each group consists of three replicates ( 3 animals each), where the $1^{\text {st }}$ group fed a basal ration free of moringa or rosemary dry leaves ( $\mathrm{R}_{1}$-control), while the $2^{\text {nd }}, 3^{\text {rd }}, 4^{\text {th }}$ and $5^{\text {th }}$ groups were fed respectively, on the same basal ration supplemented with $0.5 \%$ moringa dry leaves $\left(\mathrm{R}_{2}\right)$, $1 \%$ moringa dry leaves $\left(\mathrm{R}_{3}\right), 0.5 \%$ rosemary dry leaves $\left(\mathrm{R}_{4}\right)$ and $1 \%$ rosemary dry leaves $\left(\mathrm{R}_{5}\right)$. Temperatures have been controlled artificially to be $33.1 \pm 0.5^{\circ} \mathrm{C}$, and the level of relative humidity at $43 \pm 3 \%$. Experimental rations were offered ad lib. Growth performance was recorded weekly and hematology examination was evaluated at the end of the feeding experiment. The results showed that, moringa dry leaves (MDL) composition was on DM basis; $19.52 \% \mathrm{CP}, 7.51 \% \mathrm{EE}, 7.23 \% \mathrm{CF}, 53.08 \% \mathrm{NFE}$ and $12.66 \%$ ash and rosemary dry leaves (RDL) composition was on DM basis; $4.10 \% \mathrm{CP}, 16.32 \% \mathrm{EE}, 18.97 \% \mathrm{CF}, 52.37 \% \mathrm{NFE}$ and $5.24 \%$ ash. Feeding rabbits on rations supplemented with MDL or RDL did not influence body weight, weight gain, feed intake, feed conversion and drinking water. Hemoglobin, hematocrit, MCV, MCH, WBCs and neutrophils to lymphocytes ratio were improved with rations contained MDL or RDL $(0.5 \%$ or $1 \%)$ than control. In addition, platelets count, neutrophils and lymphocytes were not affected by feeding treatments. Under the conditions of the present study, it is concluded that, MDL and RDL supplementation might have positive effects on growing rabbits reared under heat stress conditions when supplemented to rations at $0.5 \%$ or $1.0 \%$.

Keywords: Moringa, rosemary, natural antioxidants, rabbits, growth performance and hematology.

\section{INTRODUCTION}

Oxidative stress has been long recognized to endanger cell which is associated with increments of free radicals.Reactive oxygen and nitrogen species (free radicals) are essential to detoxification, chemical signaling and immune function. They are continuously produced in the animal body and they are controlled by endogenous enzymes (superoxide dismutase, glutathione peroxidase and catalase). When there is an over-production of these species, an exposure to external oxidant substances or a failure in the defense mechanisms, damage to valuable biomolecules (DNA, lipids, proteins) may occur (Aruoma, 1998). This damage has been associated with an increased risk of cardiovascular disease, cancer and other chronic diseases.Antioxidants are molecules that neutralize free radicals mainly by scavenging them and converting them to stable form, thereby preventing or slowing down the deleterious effect of these reactive species to the cellular components. The antioxidant hypothesis says that 'as antioxidants can prevent oxidative damages, increased intakes from the diet will also reduce the risks of chronic diseases' (Stanneret al., 2004).Antioxidants also can control thedegenerative diseases where the oxidative damage has been implicated. 
A major strategy to reduce the effect of heat stress on animals is to alter the environment through the use of sheds, fans or evaporative cooling (Bucklin et al., 1991). Such practices are sometimes not possible or highly expensive. This necessitates trying other strategies to counteract the adverse effects of heat stress such as supplementation of natural antioxidants to animal diets. Several plant extracts and different classes of phytochemicals have been shown to have antioxidant activity (Zheng and Wang, 2001). The search for newer natural antioxidants, especially of plant origin, has ever since increased.

Moringa oleifera (The Miracle Tree) is the most widely cultivated species of the genus moringa. Moringa oleifera has the ability to prevent effectively, morphological changes and oxidative damage by enhancing the activities of antioxidant enzymes, reducing the intensity of lipid peroxidation and reducing generation of free radicals (Sreelatha and Padma, 2009).Moringa oleifera leaves have multiple antioxidants with high levels such as phenolic acids (Gallic, chlorogenic, ellagic and ferulic acid), glucosinolates and flavonoids (kaempferol, quercetin and rutin) Mbikay (2012).Furthermore, moringa dry leaves have been reported to be a valuable source of â-carotene (precursorof vit. A) and vitamins (B-complex, C, D and K) DorgaandTandon (1975). Moringa dry leaves have positive effects on hematological measurements of rabbits (ChinweandIsitua, 2010). Recently, El-Badawiet al. (2014) reported that improvement in nutrients digestibilities, dietary $\mathrm{N}$ utilization, growth performance and carcass dressing percentage have been recorded for growing rabbits fed diets supplemented with moringa dry leaves by levels $0.15 \%$ and $0.30 \%$, while adverse effects have been established by using $0.45 \%$.

Rosemary (Rosmarinusofficinalis) is herbal plant have needle-like leaves and white, pink, purple, or blue flowers, native to the Mediterranean region.Through natural antioxidants, rosemary has been clearly accepted as one of the species with the highest antioxidant activity (Peng et al., 2005). The chemical analysis of rosemary showed that it has several types of antioxidants including flavonoids such as carnosol, carnosic and rosmarinic acid, and volatile oils (Okamura et al., 1994; Angeliniet al., 2003).

So, this study was conducted to investigate the impact of supplementing diets of growing rabbit with natural antioxidants such as moringa or rosemary dry leaves on growth performance and hematological changes under heat stress conditions.

\section{MATERIALS AND METHODS}

The present study was carried out at the rabbits breeding farm (station) and the Poultry Physiology Laboratory, Poultry Production Department, Faculty of Agriculture, Ain Shams University, and Animal Production Department, National Research Centre, during the period from January to April 2014.

\section{Plant Collection and Preparation:}

Moringa oleifera leaves were collected from a private commercial farm cultivated solely with moringa shrubs over an area of 10 feddans (42000 $\mathrm{m}^{2}$ area). The farm is located in Nubariaprovince (160 km North Western Cairo city, Egypt). Rosemary (Rosmarinusofficinalis) leaves were collected from private plantation located in Shubra El-Kheima (north of Cairo city, Egypt). The leaves of moringa and rosemary were harvested, air-dried under shade until the moisture of collected leaves reached almost 10\%. The dry leaves were finally milled, sieved (1 mm mesh) and stored in a well tight polyethylene bags at room temperature $25^{\circ} \mathrm{C}$. Composite samples of moringa and rosemary dry leavespowder were taken in sample plastic bag for chemical analysis.

\section{Rabbit Rations:}

Five batches of rabbits ration each of $100 \mathrm{~kg}$ were formulated to contain; $32 \%$ alfalfa hay, $21 \%$ soybean meal (44\%), $16 \%$ ground yellow corn, $16 \%$ barley,9.2\% wheat bran, $3 \%$ cane-molasses, $1 \%$ lime stone, $0.6 \%$ Di-calcium phosphate, $0.5 \%$ sodium chloride, $0.5 \%$ vitamin \& mineral premix and $0.2 \%$ Methionine. Moringa and rosemary dry leaves powder were added and thoroughly hand mixed with other feed ingredients of each batch at $0,0.5 \%$ moringa, $1.0 \%$ moringa, $0.5 \%$ rosemary and $1.0 \%$ rosemary for $\mathrm{R}_{1}$ (control), $\mathrm{R}_{2}, \mathrm{R}_{3}, \mathrm{R}_{4}$ andR $\mathrm{R}_{5}$ respectively. Experimental rations were pelleted at $0.3 \mathrm{~cm}$ diameter and packed in polyethylene bags until feeding. Maximum pelleting temperature was not more than $65^{\circ} \mathrm{C}$. 


\section{Climatic Management:}

Electrical heaters have been used to control the temperature inside the station at $33.1 \pm 0.5^{\circ} \mathrm{C}$, and the level of relative humidity at $43 \pm 3 \%$. Temperatures and relative humidity levels were recorded daily using digital Hygrometer.

\section{Procedures of the Feeding Experiment:}

In a feeding trial lasted 63 days, forty five male growing New Zealand White rabbits (NZW) aged six weeks old with an average body weight of $750.0 \pm 5.8 \mathrm{~g}$ were distributed by weight in five equal groups. Experimental rabbits, within groups, have nearly similar initial body weights and they were housed in galvanized metal wire cages equipped with feeding and water troughs.The first group of animals was fed $\mathrm{R}_{1}$ (free moringa or rosemary ration-control) while $2^{\text {nd }}, 3^{\text {rd }}, 4^{\text {th }}$ and $5^{\text {th }}$ groups fed $R_{2}, R_{3}, R_{4}$ and $R_{5}$, respectively. Feed was offered ad-libtumand water was free choice during the experimental period. Amounts of drinking water were daily measured and individual body weight was weekly recorded.

\section{Slaughter Technique:}

After termination of the feeding experiment, three representative rabbits randomly taken from each group were fasted for $12 \mathrm{hrs}$. then weighed and slaughtered. During bleeding, the drained blood was collected in heparinized tubes for hematology examination.

\section{Chemical Analysis:}

Chemical composition of experimental diet, moringa dry leaves and rosemary dry leaves were analyzed according to standard methods described by (AOAC, 2005) includes; moisture, organic matter (OM), crude protein $(\mathrm{CP})$, crude fiber $(\mathrm{CF})$, ether extract (EE) and ash. While, the nitrogen free extract (NFE) was calculated by difference.

\section{Statistical Analysis:}

Collected data were subjected to the analysis of variance by using the General Linear Models Procedure (GLM) of the Statistical Analysis System (SAS, 1998) according to the following model:

Where: $Y_{\mathrm{ij}}=$ the $\mathrm{j}$ observation on the $\mathrm{i}^{\text {th }}$ treatments;

$$
\mathrm{Y}_{\mathrm{ij}}=\mu+\mathrm{T}_{\mathrm{i}}+\varepsilon_{\mathrm{ij}}
$$

$\mu=$ overall mean;

$\mathrm{T}_{\mathrm{i}}=\mathrm{a}$ fixed effect of $\mathrm{i}^{\text {th }}$ treatments;

$\varepsilon_{\mathrm{ij}}=$ a random experimental error. 1955).

Differences among treatment means were detected by using Duncan's multiple range test (Duncan,

\section{RESULTS AND DISCUSSION}

Weekly averages of temperature degrees and relative humidity are shown in Table (1). The relationship between temperature and relative humidity termed temperature-humidity index (THI). This parameter indicates the presence of heat stress or not. THI had been modified by Maraiet al. (2001) to be suitable for rabbits (as small animals) and was calculated as

$$
\mathrm{THI}=\mathrm{db}^{\circ} \mathrm{C}-\left[(0.31-0.31 \mathrm{RH})\left(\mathrm{db}{ }^{\circ} \mathrm{C}-14.4\right)\right]
$$

Where $\mathrm{db}{ }^{\circ} \mathrm{C}=$ dry bulb temperature in degrees Celsius and $\mathrm{RH}=$ relative humidity percentage/100. The values obtained are then classified as follows: $\angle 27.8=$ absence of heat stress, $27.8-28.9=$ moderate heat stress, 28.9-30.0=severe heat stress and 30.0 and more=very severe heat stress. In the present study, overall averages of temperature and relative humidity were $33.1{ }^{\circ} \mathrm{C}$ and $43 \%$, respectively. Calculated THI in present study was 29.80 indicated that the rabbits were reared under severe heat stress. 
Table (1). Average of temperature degrees $\left({ }^{\circ} \mathrm{C}\right)$, relative humidity $(\%)$ and THI through experimental period.

\begin{tabular}{lccc}
\hline Period & Temperature & Relative humidity & THI \\
\hline $1^{\text {st }}$ week & 33.2 & 41 & 29.76 \\
$2^{\text {nd }}$ week & 32.8 & 44 & 29.61 \\
$3^{\text {rd }}$ week & 33.5 & 42 & 30.07 \\
$4^{\text {th }}$ week & 32.8 & 46 & 29.72 \\
$5^{\text {th }}$ week & 32.8 & 44 & 29.61 \\
$6^{\text {th }}$ week & 33.4 & 42 & 29.98 \\
$7^{\text {th }}$ week & 33.5 & 42 & 30.07 \\
$8^{\text {th }}$ week & 32.7 & 44 & 29.52 \\
$9^{\text {th }}$ week & 32.9 & 46 & 29.80 \\
\hline Overall & 33.1 & 43 & 29.80 \\
\hline
\end{tabular}

\section{Chemical Analysis:}

Results of chemical analysis in Table (2) showed that moringa dry leaves had high contents of CP (19.52\%), EE (7.51\%), ash (12.66\%) and NFE (53.08\%) but low content of CF (7.23\%). Also, the chemical composition of rosemary dry leaves had high contents of CF (18.97\%), EE (16.32\%) and NFE (52.37\%) but low contents of ash (8.24\%) and CP (4.10\%). previous studies reported different chemical contents of moringa leaves. Ilyaset al. (2015) found that the moringa dry leaves had high percentage of CP $(28.11 \%)$ and CF (19.61\%) \& low content of EE (2.82\%) and NFE (38.97\%). Also, El-Badawiet al. (2014) showed that moringa dry leaves had a high level of CP (31.68\%), EE (8.78\%) \& ash (14.88\%) and low content of CF $(6.41 \%)$ \& NFE (38.25\%). Similar to the results of present study, Ogbe and Affiku (2011) showed that moringa dry leaves had CP (17.01\%), CF (7.09\%), EE (2.11\%) and ash (7.93\%). Different values of chemical analysis of moringa dry leaves in multiple studies could have been referred to the differences in climatic conditions, genetic reasons and the type of soil. Generally, previous studies confirmed that moringa leaves have a high content of $\mathrm{CP}$ and minerals needed by humans and animals for growth and better health.

Table (2). Chemical composition of experimental ration, moringa dry leaves and rosemary dry leaves.

\begin{tabular}{lccc}
\hline Item & Experimental ration & Moringa dry leaves & Rosemary dry leaves \\
\hline Moisture, \% & 9.04 & 7.92 & 7.69 \\
\hline DM composition, \% & & & \\
OM & 89.47 & 87.34 & 91.76 \\
CP & 16.81 & 19.52 & 4.10 \\
CF & 8.42 & 7.23 & 18.97 \\
EE & 3.79 & 7.51 & 16.32 \\
NFE & 60.45 & 53.08 & 52.37 \\
Ash & 10.53 & 12.66 & 8.24 \\
\hline
\end{tabular}

As the present study, Ghazalah and Ali (2008) found that rosemary leaves had CP (5.12\%), CF $(19.40 \%)$, EE (15.40\%), ash (7.06\%) and NFE (44.52\%). Few studies that analyzed the chemical components of rosemary leaves, given the most attention directed to the oils extracted from the leaves because it has a high content of antioxidants.

Chemical composition of experimental ration shown in Table (2) illustrated that the ration contained CP $(16.81 \%), \mathrm{CF}(8.42 \%), \mathrm{EE}(3.79 \%)$ and ash $(10.53 \%)$, and it was within the limits recommended by the NRC (1977) for rabbit's nutrition.

Growth Performance: Body weight gain, average daily gain (ADG), feed intake and feed conversion ratio of rabbits fed experimental rations are shown in Table (3). There are no significant differences between the experimental groups, but the data mentioned that there is a numerical increase in final weight and body weight gain of $R_{2}$ and $R_{3}$ groups compared with the control group $\left(R_{1}\right)$, while there is a numerical decrease 
in $\mathrm{R}_{4}$ and $\mathrm{R}_{5}$ groups compared with control. Feed intake and feed conversion ratio (FCR) had no significant differences among the experimental groups, however $R_{2}$ and $R_{3}$ groups have the best numerical value of FCR compared with other groups. El-Badawi et al. (2014) showed that weight gain and average daily gain of rabbits fed 0.15 and $0.30 \%$ moringa supplemented rations were higher $(\mathrm{P}<0.05)$ than those fed $0 \%$ or $0.45 \%$ moringa rations, the feed conversion was of lower $(\mathrm{P}<0.05)$ values for rabbits fed $0.15 \%$ and $0.30 \%$ than those fed $0 \%$ and $0.45 \%$. In the same trend, Banjo (2012) reported that inclusion of moringa significantly $(\mathrm{P}<0.05)$ enhanced weight gain of birds at $2 \%$ level of inclusion but did not affect feed intake or feed conversion ratio. El-Tazi (2012) showed that broiler chicks fed on 5\% moringa oleifera leaves meal (MOLM) diet scored heaviest body weight, highest total feed intake with the best feed conversion ratio compared with birds fed on 0,3 and 7\% MOLM. The previous studies did not mention any adverse effect on growth rate with increasing moringa replacement levels. Currently we are in need of further studies so that we can know the exact contents of the moringa so we can understand the different effects on the animal's performance.

Table (3). Growth performance and water consumption of experimental groups.

\begin{tabular}{|c|c|c|c|c|c|c|c|}
\hline \multirow{2}{*}{ Item } & \multicolumn{5}{|c|}{ Experimental groups } & \multirow{2}{*}{ SEM } & \multirow{2}{*}{ Significancy } \\
\hline & R1 & $\mathrm{R} 2$ & R3 & $\mathrm{R} 4$ & R5 & & \\
\hline Initial weight, $g$ & 755 & 757 & 752 & 751 & 755 & 5.8 & NS \\
\hline Final weight, $\mathrm{g}$ & 1962 & 2020 & 2020 & 1911 & 1907 & 142.5 & NS \\
\hline Body weight gain, $g$ & 1207 & 1263 & 1268 & 1160 & 1152 & 121.5 & NS \\
\hline Average daily gain, $g$ & 19.2 & 20.1 & 20.1 & 18.4 & 18.3 & 2.2 & NS \\
\hline Feed intake, (g/animal) & 4502 & 4130 & 4603 & 4559 & 4378 & 340 & NS \\
\hline Feed conversion & 3.73 & 3.27 & 3.63 & 3.93 & 3.80 & 0.30 & NS \\
\hline Drinking water, $\mathrm{ml}$ & 340 & 378 & 444 & 350 & 415 & 80 & NS \\
\hline $\begin{array}{l}\text { Drinking water of DM intake, } \\
\mathrm{ml} / \mathrm{g}\end{array}$ & 4.47 & 4.32 & 4.05 & 4.84 & 4.11 & 1.37 & NS \\
\hline
\end{tabular}

SEM=Standard error of means

$N S=$ non-significant

Ghazalah and Ali (2008) reported that broiler chicks fed 0.5\% rosemary leaves meal exhibited higher body weights, greater weight gain and better feed conversion compared with chicks fed $1 \%$ or $2 \%$ rosemary leaves meal. Like our study findings, Erdelyi et al. (2008) showed that rosemary oil supplementation to growing rabbit diets by level of $0.15 \%$ showed some beneficial, but not statically significant effects. Although the large effect of rosemary leaves on hematological status asit will be shown later, there is no positive effect (or negative) on growth performance of growing rabbits.

The response of rabbit'sbody weight to rations supplemented with moringa or rosemary was observed during the last three weeks of feeding (Figure 1). Body weight development curve showed clear positive effect of feeding $\mathrm{R}_{2}$ and $\mathrm{R}_{3}\left(0.5 \%\right.$ \& $1 \%$ moringa, respectively), while with rosemary supplementation $\mathrm{R}_{4}$ and $\mathrm{R}_{5}(0.5 \%$ \& $1 \%$ rosemary, respectively) there was slight decrease (non-significant) in body weight development especially in the last two weeks of the feeding experiment.

Figure (1): Body weight development of rabbits fed experimental rations.

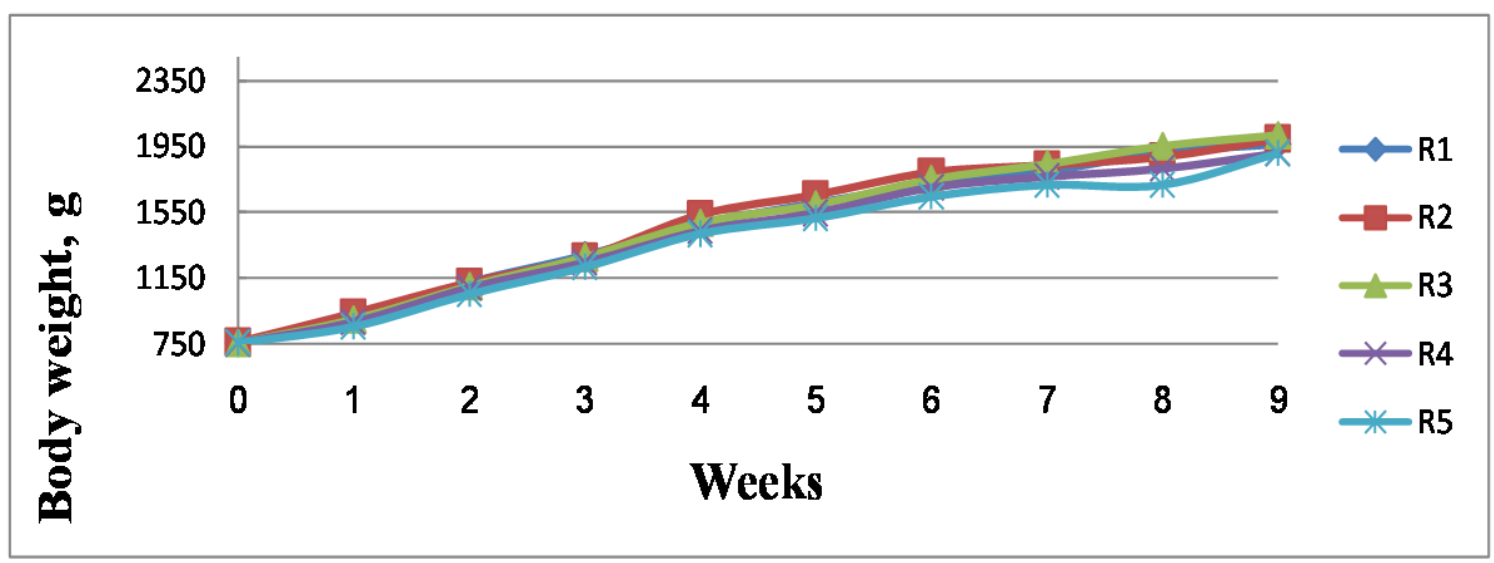


Dietary treatments had no significant effect $(\mathrm{P}>0.05)$ on drinking water or drinking water relative to DM intake (ml/g), however there was a slight increase in volume of drinking water with the high levels of supplementation either moringa or rosemary $\left(\mathrm{R}_{3} \& \mathrm{R}_{5}\right)$. Studies about the effect of moringa or rosemary supplementation on water consumption are few. El-Badawi et al. (2014) mentioned that drinking water relative to DM intake $(\mathrm{ml} / \mathrm{g})$ was significantly $(\mathrm{P}<0.05)$ lower for rabbits fed $0.30 \%$ or $0.45 \%$ moringa supplementation in comparison to control ( $0 \%$ moringa) and $0.15 \%$ moringa ration.

Generally, values of drinking water in this study were higher than the normal rates of rabbits that reared under normal conditions. These results were in agreement with those reported by Marai et al. (2002) who found that rabbits exposed to environmentalorbiological stresses decreased their feed intake, feed utilization and increase water retention particularly in hot climatic conditions. Also, Habeeb et al. (1997) showed that the daily water consumption of New Zealand White rabbit recorded $331 \pm 6 \mathrm{ml} / \mathrm{animal}$ under summer conditions of Egypt.

\section{Hematological Examination:}

Hematological parameters ofslaughtered rabbits in experimental groups are presented in Table (4). Hemoglobin values showed significant $(\mathrm{P}<0.05)$ increase in $\mathrm{R}_{3}, \mathrm{R}_{4}$ and $\mathrm{R}_{5}$ groups $(13.83,14.60$ \& 15.53 $\mathrm{g} / \mathrm{dl}$, respectively) compared with the control one $\left(\mathrm{R}_{1}\right)$. The highest values of hemoglobin have been observed in rabbits fed diets supplemented with rosemary. The count of red blood cells (RBCs) has been differed significantly $(\mathrm{P}<0.05)$ among experimental groups. The lowest value of RBCs has been recorded in group fed diet supplemented with $1 \%$ rosemary $\left(\mathrm{R}_{5}\right)$, while the highest value was recorded for control group $\left(\mathrm{R}_{1}\right)$. Data showed in Table (4) indicated that hematocrit \%, mean corpuscular volume (MCV), mean corpuscular hemoglobin $(\mathrm{MCH})$, white blood cells (WBCs) and neutrophils to lymphocytes ratio (N/L) have been differed significantly $(\mathrm{P}<0.01)$ among experimental groups. Mean corpuscular hemoglobin concentration (MCHC), platelets count, neutrophils, lymphocytes, monocytes, basophils and eosinophilswere not significantly affected among experimental groups.

Table (4). Blood hematology of slaughtered rabbits in experimental groups.

\begin{tabular}{|c|c|c|c|c|c|c|c|c|}
\hline \multirow[t]{2}{*}{ Item } & \multicolumn{5}{|c|}{ Experimental groups } & \multirow{2}{*}{$\begin{array}{c}\text { Normal } \\
\text { range } * * *\end{array}$} & \multirow[t]{2}{*}{ SEM } & \multirow[t]{2}{*}{ Sig. } \\
\hline & $\mathrm{R} 1$ & $\mathrm{R} 2$ & R3 & $\mathrm{R} 4$ & R5 & & & \\
\hline $\begin{array}{l}\text { Hemoglobin, } \\
(\mathrm{g} / \mathrm{dl})\end{array}$ & $12.86^{\mathrm{c}}$ & $13.60^{\mathrm{bc}}$ & $13.83^{\mathrm{abc}}$ & $14.60^{\mathrm{abc}}$ & $15.53^{\mathrm{ab}}$ & $11.5-15.1$ & 1.28 & * \\
\hline RBCs, $\left(\times 10^{6} / \mu \mathrm{l}\right)$ & $6.03^{\mathrm{a}}$ & $5.47^{\mathrm{ab}}$ & $5.06^{\mathrm{abc}}$ & $5.65^{\mathrm{ab}}$ & $4.28^{\mathrm{c}}$ & $3.7-7.5$ & 0.62 & * \\
\hline Hematocrit, \% & $41.6^{\mathrm{d}}$ & $43.8^{\mathrm{cd}}$ & $44.5^{\mathrm{cd}}$ & $46.8^{\mathrm{bcd}}$ & $53.7^{\mathrm{a}}$ & $36.6-47.4$ & 3.5 & $* *$ \\
\hline $\mathrm{MCV}, \mathrm{mm}^{3}$ & $69.36^{\mathrm{b}}$ & $80.13^{\mathrm{b}}$ & $91.13^{\mathrm{b}}$ & $82.83^{\mathrm{b}}$ & $125.53^{\mathrm{a}}$ & $58-79.6$ & 11.65 & $* *$ \\
\hline $\mathrm{MCH}$ & $21.43^{\mathrm{b}}$ & $24.86^{\mathrm{b}}$ & $28.30^{\mathrm{b}}$ & $25.83^{\mathrm{b}}$ & $36.30^{\mathrm{a}}$ & $19.2-29.5$ & 3.85 & $* *$ \\
\hline $\mathrm{MCHC}$ & 32.33 & 32.20 & 32.13 & 32.03 & 34.70 & $31.1-37.0$ & 1.11 & NS \\
\hline Platelets & 191 & 310 & 254 & 193 & 189 & $112-795$ & 86 & NS \\
\hline $\begin{array}{l}\text { WBCs }\left(\times 10^{3} / \mu \mathrm{l}\right) \\
\text { Neutrophils, } \%\end{array}$ & $\begin{array}{l}15.03^{\mathrm{a}} \\
36.00\end{array}$ & $\begin{array}{l}8.47^{b c} \\
27.67\end{array}$ & $\begin{array}{l}8.40^{\mathrm{bc}} \\
28.00\end{array}$ & $\begin{array}{l}6.70^{c} \\
29.00\end{array}$ & $\begin{array}{l}9.27^{\mathrm{bc}} \\
26.67\end{array}$ & $\begin{array}{c}5.2-16.5 \\
34-70\end{array}$ & $\begin{array}{l}1.45 \\
7.04\end{array}$ & $\begin{array}{l}* * \\
\text { NS }\end{array}$ \\
\hline Lymphocytes, $\%$ & 60.67 & 68.67 & 67.00 & 68.00 & 70.00 & $43-80$ & 6.93 & NS \\
\hline Monocytes, \% & 1.33 & 1.33 & 2.00 & 1.00 & 1.33 & $0-4$ & 0.44 & NS \\
\hline Basophils, \% & 1.00 & 1.00 & 1.00 & 1.00 & 1.00 & $0-0.84$ & 0.22 & NS \\
\hline Eosinophils, \% & 1.00 & 1.33 & 2.00 & 1.00 & 1.00 & $0-2$ & 0.85 & NS \\
\hline $\mathrm{N} / \mathrm{L}$ ratio & $0.59^{\mathrm{a}}$ & $0.40^{\mathrm{b}}$ & $0.42^{\mathrm{b}}$ & $0.43^{\mathrm{b}}$ & $0.38^{\mathrm{b}}$ & 0.55 & 0.04 & $* *$ \\
\hline
\end{tabular}

Unlike our observation, Nuhu (2010) stated that offering weaned rabbits a diet containing moringa leaf meal had no significant $(\mathrm{P}>0.05)$ effect on hemoglobin, packed cell volume, red blood cells and white blood cells. On the same side, Ewuola et al. (2012) reported that inclusion of MOLM to rabbit diets has no significant effect on hematocrit, RBCs, WBCs, MCV and hemoglobin.Also,European Food Safety Authority (2008) reported that the effect of adding rosemary leaves extract to diets of rats has no significance changes in hematology parameters, and no microscopic changes. In addition, Al-Shuwaili 
(2014) did not find any significant difference in hematocrit, WBCs, RBCs and hemoglobin of broiler chickens that fed on diets supplemented with $0.5 \%$ rosemary dry leaves.

On the other hand, our findings werein agreement with Ebenebe et al. (2012) who reported that adding rabbit rations with MOLM resulted in obvious increase of hemoglobin and hematocrit, and significant decrease in WBCs. Onu and Aniebo (2011) stated that inclusion of MOLM in starter broiler diets resulted in improvement of hematocrit, MCV and hemoglobin.

It is possible that, the beneficial effect of supplementing moringa to rabbit diets due to the presence of a high content of phytochemical compounds acting as antioxidants, such asâ-carotene (precursor of vit. A) and vitamin C. Although the number of RBCs decreased among groups compared with the control one, the hemoglobin level has been increased and this is due to the impact of both of moringa and rosemary to increase the volume of red blood cells (MCV) which increases the synthesis of hemoglobin and transportation of oxygen necessary for the metabolism.

\section{CONCLUSION}

Under the conditions of the present study, it could be concluded that inclusion of Moringa oleifera dry leaves or rosemary dry leaves in growing rabbit rations as a natural source of antioxidants is recommended to improve hematological status without adverse effects on growth performance. More future studies are needed to understand complete effects and proper supplementation dosage of moringa and rosemary leaves in rations of rabbits.

\section{REFERENCES}

Al-Shuwaili, M.A. (2014). The effect of adding (Rosemarinusofficinalis) and (thymus vulgaris) to broilers diet on immune response and some physiological parameters of broilers. J. Kerbala Univ., 12(1): 92-97.

Angelini LG.; G. Carpanese; P.L. Cioni; T. Morelli; M. Macchia and G. Flamini (2003). Essential oils from Mediterranean lamiaceae as weed germination inhibitors. J. Agric. Food Chem., 51: 6158-6164.

AOAC (2005). Official Methods of Analysis, 18 $\underline{\text { th }}$ ed.Association of Official Analytical Chemists, Washington, DC, USA.

Aruoma, I.O. (1998). Free radicals, oxidative stress, and antioxidants in human health and disease. J. Am. Oil Chemists' Society, 75(2): 199-212.

Banjo, O.S. (2012). Growth and performance as affected by inclusion of Moringa oleifera leaf meal in broiler chicks diet. J. Bio. Agric. Healthcare, 2(9): 35-38.

Bucklin R.A.; L.W. Turner; D.K. Beede; D.R. Bray and R.W. Hemken (1991). Methods to relieve heat stress for dairy cows in hot, humid climates. Appl. Eng. Agric., 7: 241- 47.

Chinwe, C. and N. Isitua (2010). Studies on the hematological impact of Moringa oleifera in rabbits. A poster presented at $2^{\text {nd }}$ International Conference on Applied Biotechnology, October 25-27, Khartoum, Sudan.

Dorga, P.D.S. and S. Tandon (1975). Vitamin content in moringa. J. Current Sci., 44: 30-31.

Duncan, D.B. (1955). Multiple range and multiple "F" test. Biometrics, 11: 1-42.

Ebenebe, C.I.; C.O. Umegechi; Aniebo and B.O. Nweze (2012). Comparison of haematological parameters and weight changes of broiler chicks fed different levels of Moringa oleifera diet. Inter. J. Agri. Biosci., 1(1): 23-25.

El-Badawi, A.Y.; H.A.A. Omer; A.A. Abedo and M.H.M. Yacout (2014). Response of growing New Zealand White rabbits to rations supplemented with different levels of Moringa oleifera dry leaves. Global Veterinaria, 12(4): 573-582.

El-TaziSafa, M.A. (2012). Effect of feeding different levels of Moringa oleifera leaf meal on the performance and carcass quality of broiler chicks. Int. J. Sci. Res., 3(5): 147-151.

Erdelyi, M.; Zs. Matics; Zs. Gerencsér; Z. Princz; Zs. Szendrı and M. Mézes (2008). Study of the effect of Rosemary (Rosemarinusofficinalis) and garlic (Allium sativum) essential oils on the performance of rabbit. $9^{\text {th }}$ World Rabbit Congress, June 10-13, Verona, Italy.

European Food Safety Authority (2008). Scientific opinion of the panel on food additives, flavourings, processing aids and materials in contact with food on a request from the commission on the use of rosemary extracts as a food additive. EFSA J., 721: 1-29. 
Ewuola, E.O.; O.A. Jimoh; O.V. Atuma and O.D. Soipe (2012). Hematological and serum biochemical response of growing rabbits fed graded levels of Moringa oleifera leaf meal.Proceedings $10^{\text {th }}$ World Rabbit Congress, September 3-6, Sharm El- Sheikh, Egypt, pp: 679-683.

Ghazalah, A.A. and A.M. Ali (2008). Rosemary leaves as a dietary supplement for growth in broiler chickens. Int. J. Poult. Sci., 7(3): 234-239.

Habeeb, A.A.M.; I.F.M. Marai; A.M. El-Maghawry and A.E. Gad (1997). Growing rabbits as affected by salinity in drinking water under winter and hot summer conditions of Egypt. Egyptian J. Rabbit Sci., 7(2): 81-94.

Hewitt, C.D.; D.J. Innes; J. Savory and M.R. Wills (1989). Normal biochemical and hematological values in New Zealand White rabbits. Clin. chem., 35(8): 1777-1779.

Ilyas, M.; M.U. Arshad; F. Saeed and M. Iqbal (2015). Antioxidant potential and nutritional comparison of moringa leaf and seed powders and their tea infusions. J. Anim. Plant Sci., 25(1): 226-233.

Marai, I.F.M.; A.A.M. Habeeb and A.E. Gad (2002). Rabbits' productive, reproductive and physiological performance traits as affected by heat stress: a review. Livestock Prod. Sci., 78: 71-90.

Marai, I.F.M.; M.S. Ayyat and U.M. Abd El-Monem (2001). Growth performance and reproductive traits at first parity of New Zealand White female rabbits as affected by heat stress and its alleviation under Egyptian conditions. J. Trop. Anim. Health Prod., 33: 1-12.

Mbikay, M. (2012). Therapeutic potential of Moringa oleifera leaves in chronic hyperglycemia and dyslipidemia: a review. Front Pharmacol., 3:24.

NRC (1977). National Research Council. Nutrient requirements of rabbits, National Academy of Science, Washington, DC, USA.

Nuhu, F. (2010). Effect of moringa leaf meal (MOLM) on nutrient digestibility, growth, carcass and blood indices of weaner rabbits. M.Sc., Fac. Agric. Natural Res., Kwame Nkrumah Univ. Sci. Tech., Kumasi, Ghana.

Ogbe, A.O. and J.P. Affiku (2011). Proximate study, mineral and anti-nutrient composition of Moringa oleifera leaves harvested from Lafia, Nigeria: Potential benefits in poultry nutrition and health. J. Microbio., Biotechno. Food Sci., 1(3): 296-308.

Okamura, N.; H. Haraguchi; K. Hashimoto and A. Yagi (1994). Flavonoids in Rosmarinusofficinalis leaves. Phytochemistry, 37: 1463-1466.

Onu, P.N. and A.O. Aniebo (2011). Influence of Moringa oleifera leaf meal on the performance and blood chemistry of starter broilers.Int. J. Food Agric. Vet. Sci., 1(1): 38-44.

Peng, Y.; J. Yuan; F. Liu and J. Ye (2005). Determination of active components in rosemary by capillary electrophoresis with electrochemical detection. J. Pharmaceutical Biomed. Analysis, 39: 431-437.

SAS (1998).SAS/STAT®User's Guide: Statistics Ver. 6.04, $4^{\text {th }}$ ed. SAS Institute Inc., Cary, NC., USA.

Sreelatha, S. and P.R. Padma (2009). Antioxidant activity and total phenolic content of Moringa oleifera leaves in two stages of maturity. J. Plant Food Human Nutri., 64: 303-311.

Stanner, S.A.; J. Hughes; C.N. Kelly and J. Buttriss (2004). A review of the epidemiological evidence for the 'antioxidant hypothesis. Public health nutr., 7(3):407-22.

Thrall, M.A.; G. Weiser; R. Allison and T.W. Campbell (2012). Veterinary Hematology and Clinical Chemistry. $2^{\text {nd }}$ ed. Wiley-Blackwell, John Wiley \& Sons, Inc., Ames, IA, USA.

Zheng, W. and S.Y. Wang (2001). Antioxidant activity and phenolic compounds in selected herbs. J. Agric. Food Chem., 49: 5165-5170. 


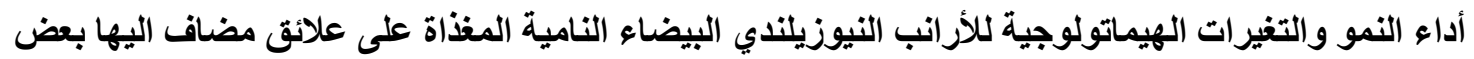

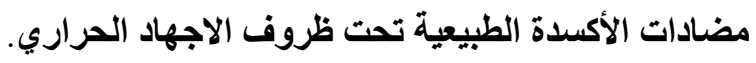

\author{
إبراهيم الورداني السيد1، علاء الدين يحيى البدوى، فاروق امام سعد هلال2، نعمة الله جمال الدين محمد على1 و أسامة \\ محمد محمد أبو ألعزب العبدا، \\ 1 قسم انتاج الدواجن- كلية الزراعة- جامعة عين شعس- القاهرة- مصر. \\ 2قسم الإنتاج الحيواني- المركز القومي للبحوثـ الدقي- جيزة- مصر.
}

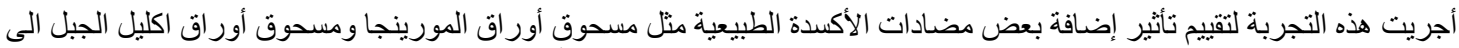

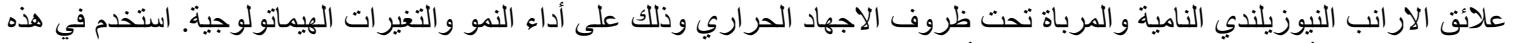

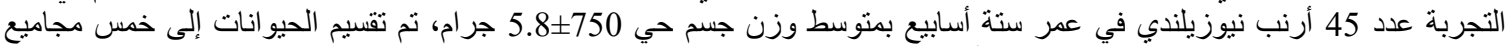

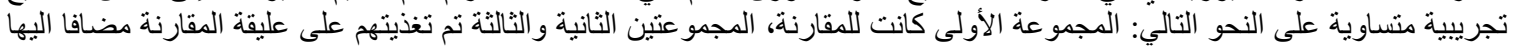

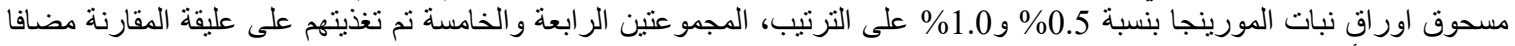

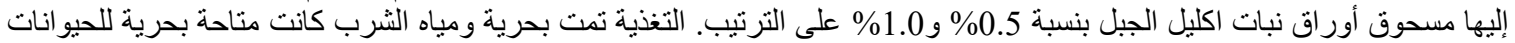

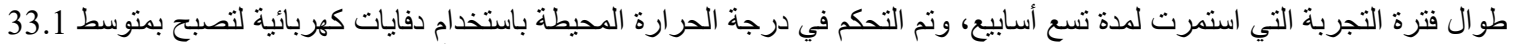

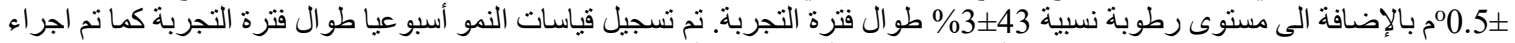

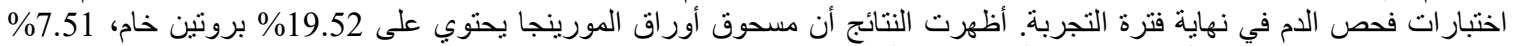

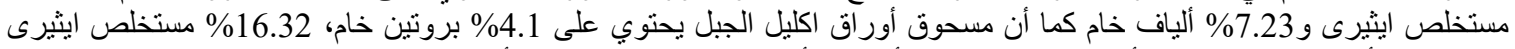

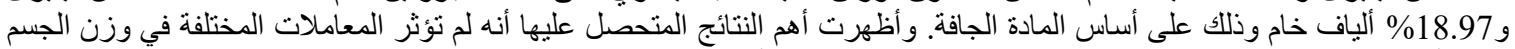

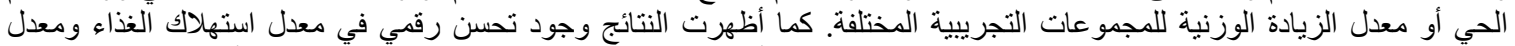

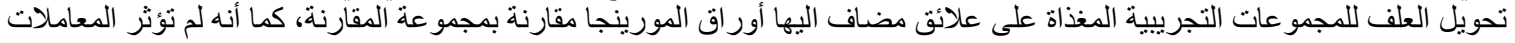

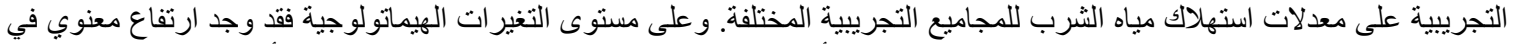

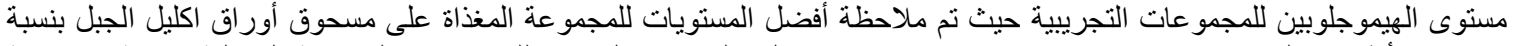

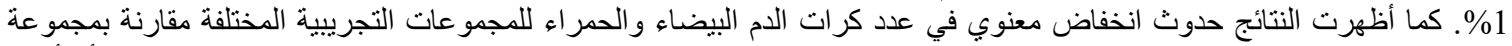

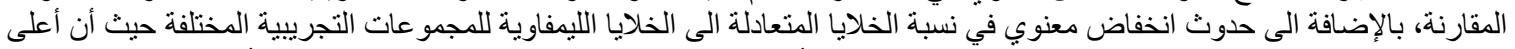

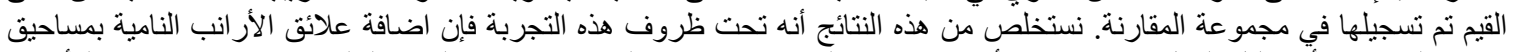

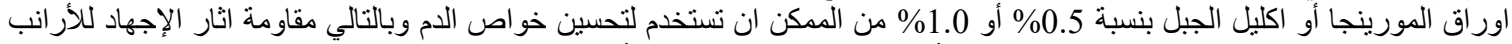
النامية المرباة تحت ظروف الاجهاد الحراري، بدون أي آثار سلبية على مستوى الأداء الإنتاجي. 